\title{
Atypical Presentation of Denny-Brown Syndrome: A Case Report and Review of Literature
}

\author{
Romeo V Porlas Jr, MD*, Scott Riley K Ong, MD, Gerard Raimon Saranza, MD, FPNA and \\ Jose Paciano B Reyes, MD, FPNA
}

Department of Neurosciences, Philippine General Hospital, University of the Philippines, Manila, Philippines

*Corresponding author: Romeo V Porlas, Jr, MD, Medical Officer III, Department of Neurosciences, Philippine General Hospital, University of the Philippines, Manila, Philippines, Tel: (+63)-977-819-0737

\begin{abstract}
Paraneoplastic subacute sensory Denny-Brown neuronopathy affects the peripheral nervous system and commonly associated with small cell lung carcinoma and with other tumor types in $14.4 \%$ of cases.

Presented is a case of 23 , female with progressive numbness of extremities and ataxia. Investigations showed diffuse sensory neuronopathy and elevated CSF IgG on CSF studies. Paraneoplastic autoantibodies revealed negative results yet imaging showed an anterior mediastinal mass, which turned B-cell lymphoma on biopsy and staining.

The recent diagnostic criteria for Sensory Neuronopathy (SNN) and Paraneoplastic Neurologic Disorders (PND) are detailed and discussed in conjunction with the clinical presentation of the patient. Of the few case reports of Lymphoma presenting as Sensory Neuronopathy, no paraneoplastic autoantibodies were detected, suggestive of possible new nosological autoantibody that is in play.
\end{abstract}

\section{Keywords}

Paraneoplastic neurological syndrome, Sensory neuronopathy, Lymphoma, Anti-Hu, Denny-Brown syndrome

\section{Introduction}

Paraneoplastic Neurologic Disorders (PND) is defined as remote, distal, non-invasive, non-metastatic effects of malignancy on the nervous system. It was said to be a rare occurrence affecting one per 10,000 patients $[1,2]$. Locally, in a study of Ngelangel, et al. there were only 8 cases of paraneoplastic syndromes out of 1205 malignancy admissions between years 1979-1983 in a tertiary hospital. No reports as to how many of these eight patients manifested with neurologic symptoms [3].

In approximately $2 / 3$ of cases, neurologic symptoms precede the diagnosis of malignancy by 6-12 months. Common tumors associated with PND includes small cell lung cancer (3-5\%), thymomas (15-20\%), and lymphomas (3-10\%) [2]. PND has a very diverse clinical presentation, including central nervous system affectation such as encephalomyelitis, subacute cerebellar degeneration, opsoclonus-myoclonus; and, peripheral nervous system involvement like subacute sensory neuronopathy and chronic gastrointestinal pseudo-obstruction and neuromuscular junction/muscle and nerve root problem including Lambert-Easton myasthenic syndrome and Dermatomyositis.

Subacute Sensory Neuronopathy (SNN) was first described by Denny-Brown in 1948 [4]. This was associated with bronchial carcinoma and in further studies, with autoantibodies specifically anti-Hu. SSN usually presents with asymmetric pain, paresthesia and dysesthesia type of numbness of the extremities. There is also a remarkable loss of proprioceptive sensibility resulting in pseudo-athetoid movements of the hands and severe instability on walking. The most frequent neoplastic finding associated with SNN is small oat cell lung cancer, but recent studies have shown that it is also seen among patients with breast cancer, ovarian cancer, sarcoma and Hodgkin's disease in $10-20 \%$ of cases $[5,6]$.

Lymphoma can affect various parts of the nervous system, but affects the peripheral nervous systems in

Citation: Porlas RV, Ong SRK, Saranza GR, Reyes JPB (2019) Atypical Presentation of Denny-Brown Syndrome: A Case Report and Review of Literature. Int J Oncol Res 2:014. doi.org/10.23937/26434563/1710014

Accepted: May 30, 2019; Published: June 01, 2019

Copyright: (C) 2019 Porlas RV, et al. This is an open-access article distributed under the terms of the Creative Commons Attribution License, which permits unrestricted use, distribution, and reproduction in any medium, provided the original author and source are credited. 
$5 \%$ of cases. Half of the peripheral nervous system involvement is accounted for by Neurolymphomatosis, direct invasion of lymphoma cells into the peripheral nervous system. The remaining half explained by Paraneoplastic Neuropathy. This paper presents an atypical presentation of a rare condition, Denny-Brown Syndrome. It aims to document another case of association of Lymphoma and Sensory Neuronopathy, to review the recent diagnostic criteria for Paraneoplastic Neurologic Disorder, and Sensory Neuronopathy specifically.

\section{Case Report}

\section{Clinical case}

A 23-year-old, right-handed, female, presented with a 5-month history of weakness and numbness of both hands. She then developed coarse, wing-beating tremors on the upper extremities, which was worse on the left than on the right. There were no reports of myalgia, muscle cramps, fasciculations, atrophy or dyskinesias. After a month, she had a gradually progressive numbness and weakness of bilateral lower extremities needing assistance in ambulation. Interval history revealed gradual evolution of coarse tremors to choreoathetoid movements, associated with worsening numbness and weakness of all extremities, difficulty handling objects and difficulty ambulating. Over the succeeding 6 months, there was an unintended weight loss of $15 \mathrm{~kg}$. No fever, loss of appetite, abdominal pain, jaundice, behavioral changes were noted. There were no other constitutional symptoms like night sweats, chills, chest pain and easy fatigability suggestive of Lymphoma. She had no other co-morbidities and there was no note of any similar illness in the family. She denied any vices. No exposure to any chemicals, pesticides or toxins were reported. She previously worked as fish vendor in Palawan islands.

On examination, she was noted to be cachectic with no jaundice, cervical lymphadenopathy, hepatosplenomegaly, no pallor, no trophic skin changes. Higher cortical function revealed astereognosis and a graphesthesia on bilateral hands. Cranial nerves were all intact, with note of relatively poor visual acuity on $20 / 70$ on bilateral eyes with numbness on the gums and mild difficulty in swallowing, brought about by decreased sensation over the soft palate region.

There was marked atrophy of the gluteal musculature but no fasciculations were noted. Choreoathetoid movements of the left arm and spontaneous clawing of fingers were seen. On manual muscle testing, she has hypotonic extremities but exhibited full range of motion against gravity and mild resistance on the right and full range of motion against gravity and very minimal resistance on the left. She had generalized hyporeflexia with no extensor toe sign nor clonus. The patient had dysmetria, which was more prominent on the left than the right but no other cerebellar signs were elicited.

The patient had patchy sensory deficits on pinprick and light touch, with sparing of the truncal region. She also had impaired vibratory and position sense on

Table 1: Electrophysiologic Examination: Nerve Conduction Velocity.

\begin{tabular}{|c|c|c|c|c|c|c|c|c|c|}
\hline \multirow[b]{2}{*}{ Nerve } & \multirow[b]{2}{*}{ Site } & \multicolumn{4}{|l|}{ Right } & \multicolumn{4}{|l|}{ Left } \\
\hline & & Dist (cm) & Lat (ms) & $\operatorname{Amp}(\mathrm{mV})$ & $\operatorname{Vel}(\mathrm{m} / \mathrm{s})$ & Dist (cm) & Lat (ms) & $\operatorname{Amp}(\mathrm{mV})$ & $\operatorname{Vel}(\mathrm{m} / \mathrm{s})$ \\
\hline \multicolumn{10}{|l|}{ MOTOR } \\
\hline \multirow[t]{3}{*}{ Median } & Wrist & 22 & 2.6 & 6.34 & \multirow[b]{3}{*}{52.3} & 21 & 2.8 & 7.45 & \multirow[b]{3}{*}{53.8} \\
\hline & Elbow & & 4.2 & 5.95 & & & 3.9 & 5.17 & \\
\hline & F-wave & & 24.4 & & & & 25.2 & & \\
\hline \multirow[t]{3}{*}{ Ulnar } & Wrist & 20 & 2 & 4.99 & \multirow[b]{3}{*}{62.5} & 20 & 1.8 & 4.49 & \multirow[b]{3}{*}{57.1} \\
\hline & Elbow & & 3 & 5.09 & & & 3.5 & 3.72 & \\
\hline & F-wave & & 25.6 & & & & 25.3 & & \\
\hline \multirow[t]{3}{*}{ Peroneal } & Ankle & 26 & 3 & 1.21 & \multirow[b]{3}{*}{32.9} & 28 & 3.5 & 2.26 & \multirow[b]{3}{*}{37.8} \\
\hline & Knee & & 7.9 & 1.23 & & & 7.4 & 2.09 & \\
\hline & F-wave & & & & & & & & \\
\hline \multirow[t]{3}{*}{ Tibial } & Ankle & 32 & 3.4 & 8 & \multirow[b]{3}{*}{37.6} & 30 & 3.4 & 10.7 & \multirow[b]{3}{*}{37.9} \\
\hline & Knee & & 8.5 & 6.54 & & & 9.2 & 8.76 & \\
\hline & F-wave & & 42.4 & & & & 43 & & \\
\hline \multicolumn{10}{|c|}{ SENSORY } \\
\hline Median & $2^{\text {nd }}$ digit & & NR & & & & NR & & \\
\hline Ulnar & $5^{\text {th }}$ digit & & NR & & & & NR & & \\
\hline Radial & $1^{\text {st }}$ digit & & NR & & & & NR & & \\
\hline Sural & Ankle & & NR & & & & NR & & \\
\hline
\end{tabular}

Absent sensory potentials on both upper and lower extremities, with normal motor potentials amplitude and conduction velocities were seen on electrophysiologic examination. 
all four extremities. She was able to maintain proper stance and standing posture but was unable to ambulate independently.

The patient was referred to ophthalmology service for slit-lamp examination, which did not reveal any Kayser-Fleicher rings, or formation suggestive of copper deposits.

\section{Investigations}

Nerve conduction studies showed absent sensory potentials with preservation of the motor amplitude potentials and normal motor nerve conduction velocities

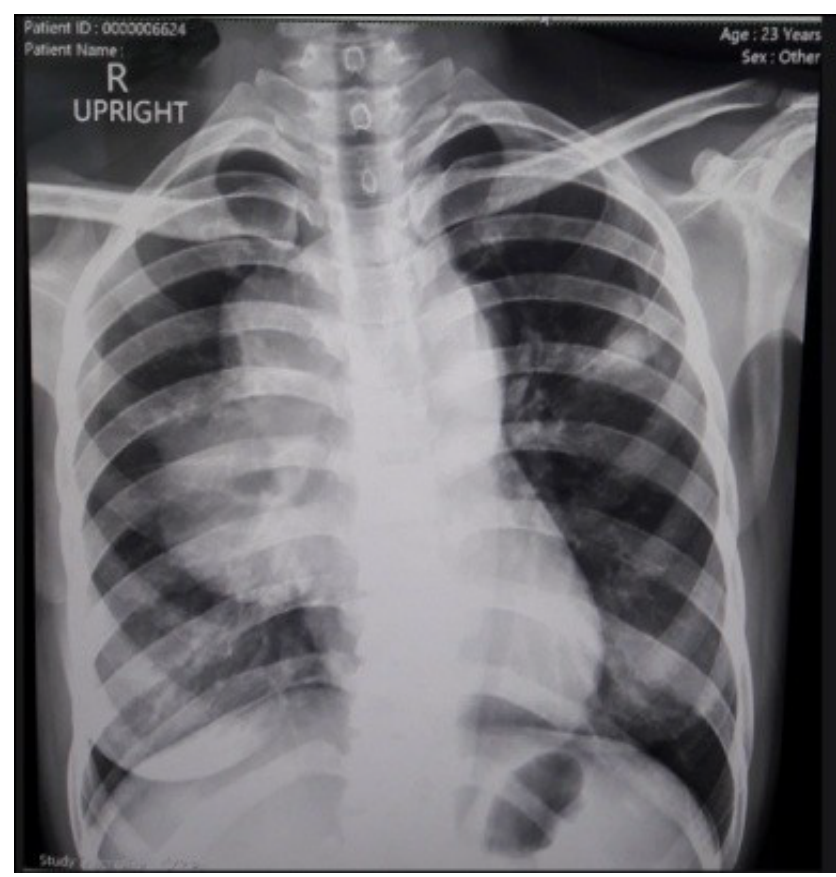

Figure 1: Chest radiograph.

Widening of mediastinum, with fairly-defined lobulated homogenous convexity in the perihilar area $(11.5 \times 6.4 \mathrm{~cm})$ was noted on Chest Radiograph.
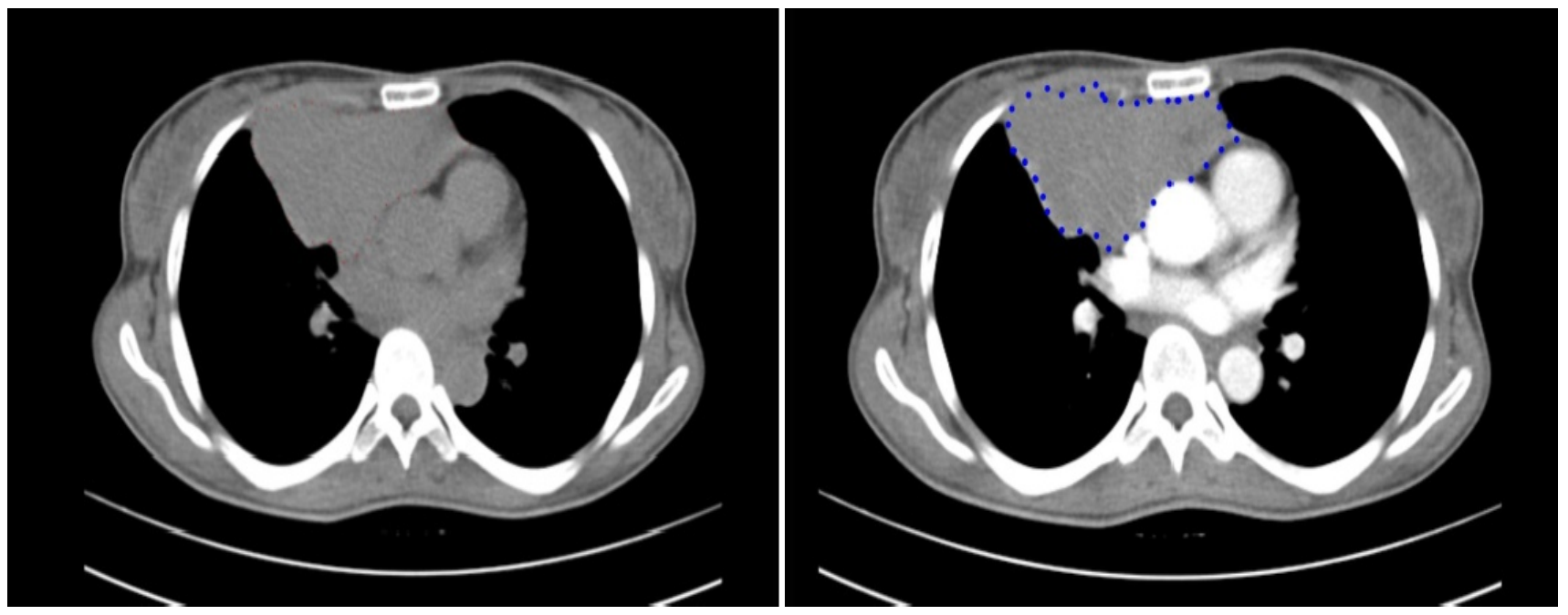

Figure 2: Chest tomography with intravenous contrast.

Chest Computed Tomography with Contrast showed solid non-enhancing mass with small areas of necrosis, measuring 9.7 $\times 8.6 \times 5.1$.
(Table 1). Electromyogram resulted to unremarkable findings.

The patient was then suspected to have Paraneoplastic Neuropathy on the basis sensory neuropathy on clinical grounds and unintended weight loss. The sensory neuropathy was confirmed via electrophysiologic exam, thus, a search for a malignancy was done. Chest computerized tomography showed an anterior mediastinal mass (Figure 1 and Figure 2).

Ultrasound Guided Biopsy of the anterior mediastinal mass was done and it showed Atypical Lymphoid Proliferation on H \& E stain (Figure 3). On Immunohistochemical staining, there was patchy membranous staining of the CD3 stain among the reactive thymocytes while there was prominent and diffuse staining of the CD20 (Figure 4), a profile compatible with a B-cell lymphoma.

Cerebrospinal Fluid (CSF) studies were done to rule out metastatic infiltration of the central nervous system, which showed RBC of 530, WBC 0, CSF glucose of $53 \%$ of serum, CSF protein normal at $46 \mathrm{mg} / \mathrm{dL}$ and elevated CSF IgG at $64.4 \mathrm{mg} / \mathrm{L}$. Serial cytologic examination of CSF also revealed negative for malignant cells.

Cranial magnetic resonance imaging with Gadolinium did not reveal any signal abnormalities on the basal ganglia and abnormal contrast enhancement on the leptomeninges, which are usually seen in Wilson's Disease and Metastatic spread of malignancies respectively.

Autoantibody testing was done at the Laboratori de Neuroimmunologia, Barcelona, Spain which showed negative for antibodies to cell surface neuronal antigens including NMDA, AMPA, GABA ${ }_{(B)}$, mGluR1, and mGluR5 receptors. Antibodies to LGI1 and Caspr2 and the classic paraneoplastic antibodies: Anti-Hu, anti-Yo, anti$\mathrm{Ma}$, anti-CV2, anti-Amphiphysin and anti-Ri were not 


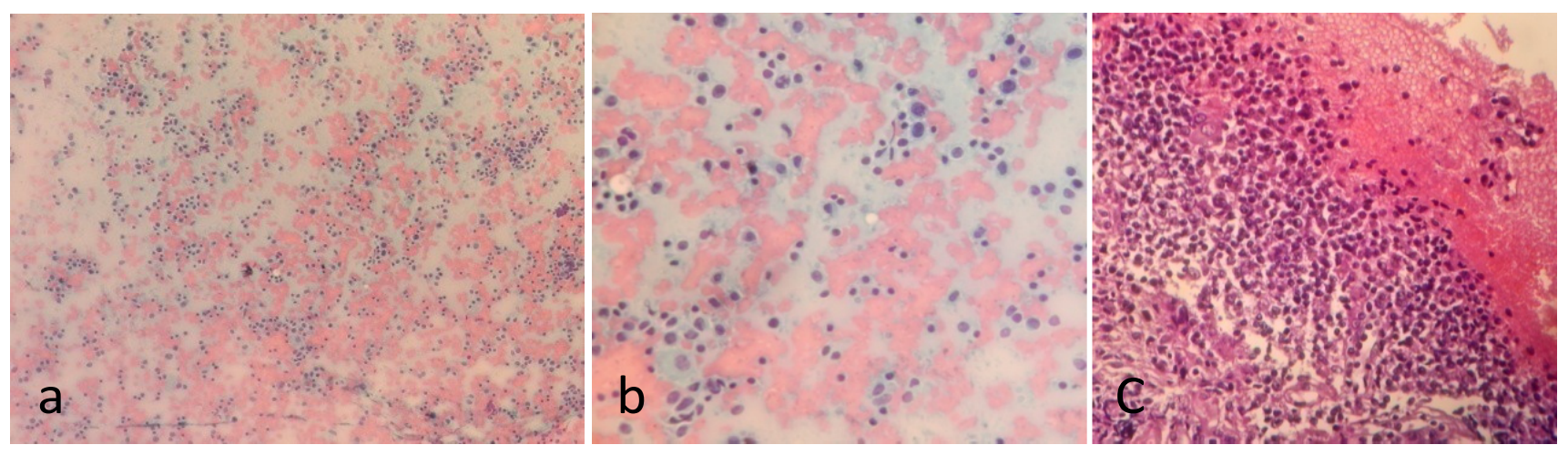

Figure 3: Photomicrograph of biopsy and cell block on haematoxylin and eosin stains, a) Lower Magnification 100x, In a sea of hemorrhage, there were small round blue cells seen; b) Biopsy Smear Higher Magnification 400x, the small round blue cells were seen to have prominent nuclei and sparse cytoplasm with atypical mitotic figures; c) Cell Block Higher Magnification 400x, there were proliferation of the discohesive round blue cells seen on smear with no epitheloid cells seen on the background.
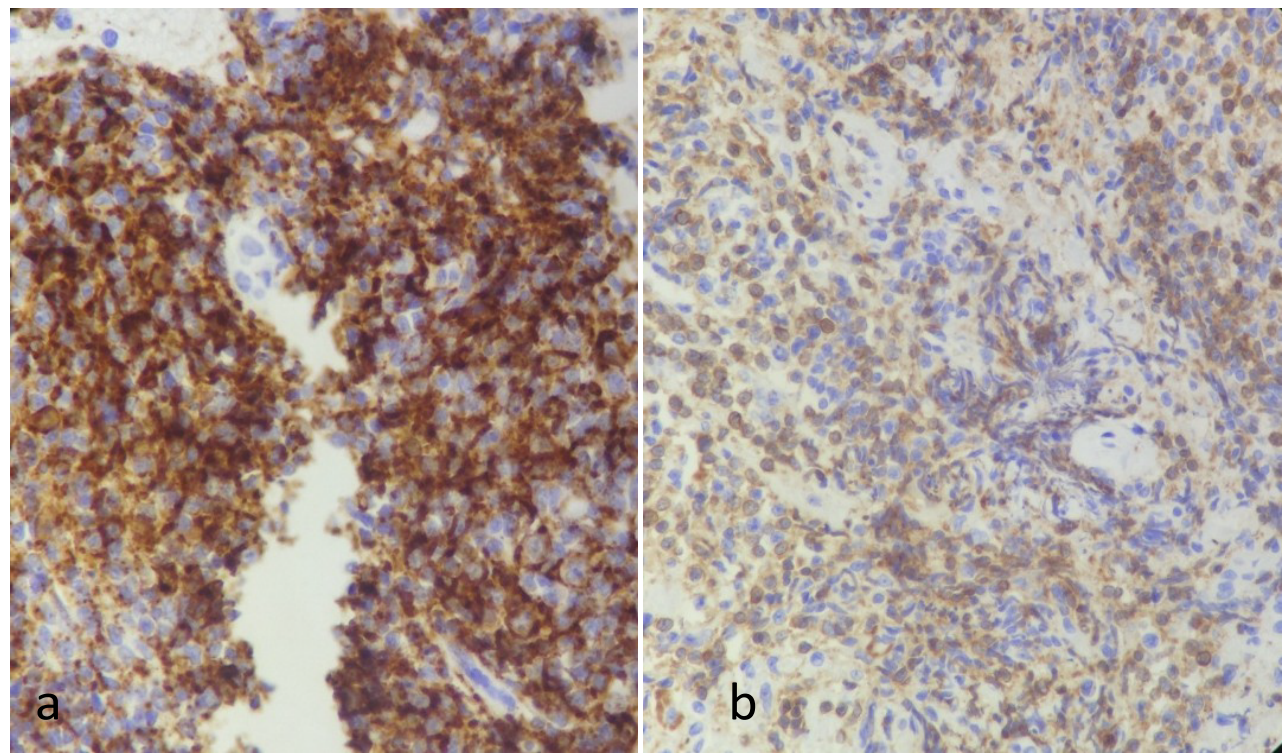

Figure 4: Photomicrography of biopsy under cd3 and cd20 immunohistochemical stains; a) Higher Magnification 400x, CD20 Staining highlighting B-cells; b) Higher Magnification 400x, CD3 Staining emphasizing thymocytes.

\section{detected.}

\section{Treatment and follow up}

The patient was treated with high-dose oral corticosteroids, Prednisone $1.5 \mathrm{mk} /$ day with no marked improvement of her symptoms. Patient was apprised of her condition, and with plan of giving R-CHOP (Rituximab, Cyclophophamide, Doxorubicin, Vincristine and Prednisone) Regimen for 6 cycles. Despite the explanation of the medical team, patient opted not to push through with chemotherapy. Most recently, she was wheelchair-bound with fair sitting balance, able to stand with assistance, less athetoid movements of the upper extremities and still has severe sensory loss on light touch and pain, and markedly impaired position and vibration sense.

\section{Discussion}

Early recognition of PND may contribute to early di- agnosis and treatment of underlying malignancy. It is significant to note PND early since it causes marked disability, more severe than that caused by the associated cancer. It is difficult to diagnose of PND requiring a triad of paraneoplastic presentation, malignancy work-up and autoantibody testing.

\section{Paraneoplastic presentation}

The aforementioned case is a Classic Paraneoplastic Neurologic Disorder, Sensory Neuronopathy (SNN). It is defined as primary degeneration of sensory neurons in dorsal root ganglia with underlying T-cell mediated immune response $[7,8]$. Camdessanche, et al. outlined a diagnostic criteria of SNN based on a case-control study involving 134 patients [9]. Using that criterion, this case falls under Probable SNN; with score of 12.7 for clinical presentation of diffuse, asymmetric sensory loss and ataxia of all limbs and nerve conduction studies consistent with SNN and diagnosis of malignancy within a 
5-year period. To make the diagnosis of SNN definitive, biopsy of the dorsal root ganglia must demonstrate loss of ganglion cells and inflammatory infiltrates surrounding the dying cells.

\section{Malignancy}

In a study of 71 patients with PND, only twenty four percent (24\%) were pure sensory neuronopathy. Among the cases of SNN, $60-73 \%$, is associated with lung carcinoma and is associated with extrathoracic malignancy: gastrointestinal, breast, ovary and lymphoid organs in $10-15 \%$ of cases $[5,6,10]$. The malignancy work up for this case is consistent with a lymphoma, making it an atypical presentation of Denny-Brown Syndrome.

\section{Autoantibodies}

Many studies dwelt on the association of lung cancer and sensory neuronopathy wherein they found out that those patients had high titers of anti-Hu antibodies. Anti-Hu antibodies are proteins expressed mainly in the neuronal nucleus and cytoplasm of the central and peripheral nervous system, causing encephalitis and neuritis respectively [11]. Conversely, Dalmau, et al. documented that seventy seven percent $(77 \%)$ of patient with elevated anti-Hu titers were found to have lung carcinoma [12]. There are also reports of association of the SNN with other autoantibodies like anti-CV2, anti-Amphiphysin and anti-Yo [10]. More importantly, SNN may be seronegative on all autoantibodies, occurring in $16 \%$ of cases. It signifies that negative result on an anti-neuronal antibody assay, does not rule out the possibility of paraneoplastic etiology $[13,14]$.

With classic presentation of sensory neuronopathy and confirmed lymphoma despite seronegative autoantibodies, this case is still considered as Definite Paraneoplastic Neurological Syndrome. Graus, et al. drafted an algorithm for the recommended diagnostic criteria of PND based on their published definition (Table 2) [15].

Edited from Graus, et al. recommended diagnostic criteria for Paraneoplastic Neurological Syndrome

\begin{tabular}{|l|l|l|l|l|}
\hline & \multicolumn{4}{|l|}{ Paraneoplastic Neurologic Disorders } \\
\hline \multirow{2}{*}{} & \multicolumn{2}{|l|}{$\begin{array}{l}\text { Classical } \\
\text { Presentation }\end{array}$} & $\begin{array}{l}\text { Non-Classical } \\
\text { Presentation }\end{array}$ \\
\cline { 2 - 5 } & Tumor (+) & Tumor (-) & Tumor (+) & Tumor (-) \\
\hline Antibody (+) & $\begin{array}{l}\text { Definite } \\
\text { PND }\end{array}$ & $\begin{array}{l}\text { Possible } \\
\text { PND }\end{array}$ & $\begin{array}{l}\text { Definite } \\
\text { PND }\end{array}$ & $\begin{array}{l}\text { Definite } \\
\text { PND }\end{array}$ \\
\hline Antibody (-) & $\begin{array}{l}\text { Definite } \\
\text { PND }\end{array}$ & Possible & Possible & $\begin{array}{l}\text { Consider } \\
\text { PND }\end{array}$ \\
& & PND & $\begin{array}{l}\text { other } \\
\text { etiology }\end{array}$ \\
\hline
\end{tabular}

Locally, there are no cases of Definite PND involving the peripheral nervous system seen in publication. Most recent case report was that of Rosales, et al. [16]. where they discussed a case of 68-year-old diagnosed with breast cancer with motor neuropathy not attributable to metastatic spread. Following the recent recommendations, that case falls under Possible PND, since the presentation of motor neuropathy is not part of the Classic Paraneoplastic Syndrome.

Upon review of publications with SSN and Lymphoma, there are only seven cases of Atypical Denny-Brown Syndrome in the literature (Table 3) [17-21]. The age ranges from 24 to 55 , with very stereotypic presentation of subacute-chronic progressive disabling paresthesia and limb ataxia. On electrophysiologic exam, all of them show decreased to absent sensory potentials. No definite pattern on CSF findings noted, probably because its CSF characteristics vary depending on the time of illness with marked pleocytosis during early phase of disease and acellular pattern in the later phase [11]. CSF findings suggestive of Denny-Brown Syndrome, are the slight elevation of total protein and evidence of increase IgG synthesis. Two of the cases are negative for anti-neuronal antibodies, suggestive of a possible new nosological autoantibody that is in play for Lymphoma.

In summary, with this additional case report of Lymphoma presenting as Sensory Neuronopathy, it can be inferred that there could be an undiscovered autoantibody produced by oncoantigens from Lymphoma. Close attention should be given to patients with lymphoma and other malignancies, since paraneoplastic neurolog-

Table 2: Diagnostic Criteria of Paraneoplastic Neurologic Disorders.

\section{Diagnostic Criteria of Paraneoplastic Neurologic Disorders \\ Definite PND}

Classic syndrome with cancer diagnosed within 5 years of neurological symptom

Non-classic syndrome that resolves or significantly improves after cancer treatment without concomitant immunotherapy, provided that the syndrome is not susceptible to spontaneous remission

Non-classic syndrome with cancer diagnosed within 5 years of nuerological symptoms development and positive neuronal antibodies

Neurological syndrome (classic or not) without cancer and with well characterized antineuronal antibodies (Hu, Yo, Ma, CV2, Ampiphysin and Ri)

\section{Possible PND}

Classic syndrome with high risk of cancer without antineuronal antibodies

Neurological syndrome (classic or not) without cancer and with partly characterized antineuronal antibodies

Non-classic syndrome with cancer within 2 years of neurological symptom development without neuronal antibodies 
Table 3: Summary table of Atypical Presentation of Denny Brown Syndrome.

\begin{tabular}{|c|c|c|c|c|c|c|c|c|}
\hline $\begin{array}{l}\text { First } \\
\text { Author } \\
\text { (Year) }\end{array}$ & Age & Sex & History & $\begin{array}{l}\text { Physical } \\
\text { Examination }\end{array}$ & $\begin{array}{l}\text { Electrophysio } \\
\text { logic Exam }\end{array}$ & $\begin{array}{l}\text { Cerebros } \\
\text { spinal Fluid } \\
\text { Studies }\end{array}$ & Tumor & $\begin{array}{l}\text { Auto- } \\
\text { antibodies }\end{array}$ \\
\hline \multirow[t]{2}{*}{$\begin{array}{l}\text { Denny- } \\
\text { Brown } \\
(1947) \\
{[4,17]}\end{array}$} & 59 & $\mathrm{~F}$ & $\begin{array}{l}\text { numbness of } \\
\text { feet, both hands } \\
\text { and the face }\end{array}$ & $\begin{array}{l}\text { sensory } \\
\text { impairment pain } \\
\text { and light touch } \\
\text { impaired position } \\
\text { and vibration } \\
\text { sense, grossly } \\
\text { ataxic }\end{array}$ & ND & $\begin{array}{l}\text { elevated } \\
\text { protein, CSF } \\
\operatorname{lgG}(+)\end{array}$ & $\begin{array}{l}\text { Bronchial } \\
\text { Carcinoma }\end{array}$ & ND \\
\hline & 71 & M & $\begin{array}{l}\text { unsteadiness } \\
\text { on walking }\end{array}$ & $\begin{array}{l}\text { diminished } \\
\text { sensation to pain, } \\
\text { poor vibration and } \\
\text { position sense, } \\
\text { grossly ataxic, } \\
\text { areflexia }\end{array}$ & ND & ND & $\begin{array}{l}\text { Oat Cell } \\
\text { Carcinoma }\end{array}$ & ND \\
\hline $\begin{array}{l}\text { Horwich } \\
\text { (1977) [18] }\end{array}$ & 38 & $F$ & $\begin{array}{l}\text { burning } \\
\text { sensation on } \\
\text { feet, numbness } \\
\text { of the hands, } \\
\text { and diffuse } \\
\text { pain and } \\
\text { paresthesia on } \\
\text { the extremities }\end{array}$ & $\begin{array}{l}\text { decreased } \\
\text { vibration, pinprick } \\
\text { and touch } \\
\text { sensations, absent } \\
\text { positions sense } \\
\text { and reflexes }\end{array}$ & $\begin{array}{l}\text { normal motor } \\
\text { conduction } \\
\text { velocities, } \\
\text { absent sensory } \\
\text { conduction } \\
\text { times }\end{array}$ & normal & $\begin{array}{l}\text { Hodgkin's } \\
\text { Lymphoma }\end{array}$ & ND \\
\hline $\begin{array}{l}\text { Brunet } \\
(1983) \text { [18] }\end{array}$ & 48 & $\mathrm{~F}$ & $\begin{array}{l}\text { violent and } \\
\text { painful } \\
\text { paresthesia }\end{array}$ & $\begin{array}{l}\text { diminished } \\
\text { proprioceptive } \\
\text { sensibility, } \\
\text { diminshed } \\
\text { sensation to } \\
\text { temperature }\end{array}$ & $\begin{array}{l}\text { partial } \\
\text { denervation } \\
\text { with preserved } \\
\text { conduction } \\
\text { velocity }\end{array}$ & normal & $\begin{array}{l}\text { Hodgkin's } \\
\text { Lymphoma }\end{array}$ & ND \\
\hline $\begin{array}{l}\text { Sagar } \\
(1982) \text { [18] }\end{array}$ & 46 & $\mathrm{~F}$ & ataxic gait & $\begin{array}{l}\text { impaired } \\
\text { proprioception and } \\
\text { vibration sense }\end{array}$ & $\begin{array}{l}\text { partial } \\
\text { denervation } \\
\text { of all hand an } \\
\text { foot muscles, } \\
\text { with decreased } \\
\text { motor } \\
\text { conduction } \\
\text { velocity, no } \\
\text { recordable } \\
\text { sensory } \\
\text { potentials }\end{array}$ & $\begin{array}{l}\text { elevated } \\
\text { protein, } \\
\text { increased CSF } \\
\operatorname{lgG}(+)\end{array}$ & $\begin{array}{l}\text { Hodgkin's } \\
\text { Lymphoma }\end{array}$ & ND \\
\hline \multirow[t]{2}{*}{$\begin{array}{l}\text { Plante- } \\
\text { Bordeneu } \\
\text { ve (1993) } \\
{[19]}\end{array}$} & 55 & $F$ & $\begin{array}{l}\text { progressive } \\
\text { numbness in the } \\
\text { toes and feet, } \\
\text { paraesthesia in } \\
\text { the left hand and } \\
\text { walking difficulty } \\
\text { numbness } \\
\text { in the toes and } \\
\text { feet, } \\
\text { paraesthesia } \\
\text { in the left } \\
\text { hand and } \\
\text { walking } \\
\text { difficulty }\end{array}$ & $\begin{array}{l}\text { distal and } \\
\text { asymmetrical } \\
\text { loss of pinprick } \\
\text { in all four limbs, } \\
\text { joint position } \\
\text { sense diminshed, } \\
\text { hyporeflexive } \\
\text { asymmetrical loss } \\
\text { of } \\
\text { pinprick in all four } \\
\text { limbs, joint position } \\
\text { sense diminished, } \\
\text { hyporeflexive }\end{array}$ & $\begin{array}{l}\text { decreased } \\
\text { sensory } \\
\text { potential } \\
\text { amplitudes, } \\
\text { motor potentials } \\
\text { and conduction } \\
\text { times were } \\
\text { within normal } \\
\text { limits }\end{array}$ & elevated protein & $\begin{array}{l}\text { Hodgkin's } \\
\text { Lymphoma }\end{array}$ & ND \\
\hline & 40 & $\mathrm{~F}$ & $\begin{array}{l}\text { paraesthesia in } \\
\text { the first three } \\
\text { fingers of both } \\
\text { hands and } \\
\text { then, after a few } \\
\text { weeks, in the } \\
\text { toes }\end{array}$ & $\begin{array}{l}\text { loss of pinprick } \\
\text { sensation over } \\
\text { the soles of } \\
\text { both feet, mild } \\
\text { impairment of distal } \\
\text { proprioception } \\
\text { in the legs and } \\
\text { generalized } \\
\text { areflexia }\end{array}$ & $\begin{array}{l}\text { decreased } \\
\text { sensory } \\
\text { potential } \\
\text { amplitudes, } \\
\text { motor potentials } \\
\text { and conduction } \\
\text { times were } \\
\text { within normal } \\
\text { limits }\end{array}$ & ND & $\begin{array}{l}\text { Hodgkin's } \\
\text { Lymphoma }\end{array}$ & ND \\
\hline
\end{tabular}




\begin{tabular}{|c|c|c|c|c|c|c|c|c|}
\hline $\begin{array}{l}\text { Cheol-Oh } \\
\text { (2004) [20] }\end{array}$ & 24 & $M$ & $\begin{array}{l}\text { tingling or } \\
\text { burning } \\
\text { sensations in } \\
\text { both hand and } \\
\text { feets } \\
\text { hands and } \\
\text { feet } \\
\text { sensations } \\
\text { in both } \\
\text { hands and } \\
\text { feet }\end{array}$ & $\begin{array}{l}\text { severe loss of } \\
\text { position and } \\
\text { vibration sense on } \\
\text { both hands and } \\
\text { feet }\end{array}$ & $\begin{array}{l}\text { no producible } \\
\text { potentials of the } \\
\text { sensory nerves, } \\
\text { motor nerves } \\
\text { are nearly } \\
\text { normal }\end{array}$ & $\begin{array}{l}\text { normal, CSF } \\
\text { negative for } \\
\text { malignant cells }\end{array}$ & $\begin{array}{l}\text { Hodgkin's } \\
\text { Lymphoma }\end{array}$ & Negative \\
\hline $\begin{array}{l}\text { Tomita } \\
\text { (2013) [21] }\end{array}$ & 63 & $F$ & $\begin{array}{l}\text { chronic } \\
\text { progressive } \\
\text { numbness } \\
\text { of all limbs }\end{array}$ & $\begin{array}{l}\text { severe sensory } \\
\text { dysfunction on } \\
\text { all modalities: } \\
\text { proprioceptive } \\
\text { and kinaesthetic } \\
\text { sensory loss }\end{array}$ & $\begin{array}{l}\text { reduction } \\
\text { of sensory } \\
\text { nerve action } \\
\text { potentials }\end{array}$ & $\begin{array}{l}\text { pleocytosis, } \\
\text { elevated } \\
\text { protein, CSF } \\
\text { negative for } \\
\text { malignant cells }\end{array}$ & Lymphoma & ND \\
\hline $\begin{array}{l}\text { Patient } \\
(2016)\end{array}$ & 23 & $F$ & $\begin{array}{l}\text { progressive } \\
\text { numbness } \\
\text { and weakness } \\
\text { of the limbs } \\
\text { with difficulty } \\
\text { ambulating }\end{array}$ & $\begin{array}{l}\text { gross ataxic } \\
\text { limbs, impaired } \\
\text { cutaneous } \\
\text { sensibility, joint } \\
\text { sense and vibration } \\
\text { sense, diminished } \\
\text { reflexes }\end{array}$ & $\begin{array}{l}\text { diffuse sensory } \\
\text { neuronopathy }\end{array}$ & $\begin{array}{l}\text { normal protein, } \\
\text { elevated CSF } \\
\text { lgG }\end{array}$ & Lymphoma & Negative \\
\hline
\end{tabular}

"ND - not done; The first two rows described the first two patients reported to have sensory neuronopathy with associated lung carcinoma, while the succeeding cases depicted the association between Sensory neuropathy and Lymphoma.

ical syndromes precede the diagnosis of malignancy in 60 percent of cases. Early detection of paraneoplastic neurological syndromes may be life-saving since it can pave the way in early diagnosis of malignancy.

\section{References}

1. Darnell RB, Posner JB (2003) Paraneoplastic Syndromes Involving the Nervous System. N Engl J Med 349: 15431554.

2. Pignolet BS, Gebauer CM, Liblau RS (2013) Immunopathogenesis of paraneoplastic neurological syndromes associated with anti-Hu antibodies: A beneficial antitumor immune response going awry. Oncoimmunology 2: e27384.

3. Apolinar-Ngelangel (1987) Carcinoid tumor case series from 1972 to 1982 in the Philippine General Hospital. Philippine Journal of Internal Medicine. HERDIN database.

4. Denny Brown (1947) Primary Sensory Neurpathy with Muscular changes associated with carcinoma.

5. Vedeler CA, Antoine JC, Giometto B, Graus F, Grisold W, et al. (2009) Chapter 31: Paraneoplastic neurological syndromes. 447-457.

6. Graus F, Keime-Guibert F, Reñe R, Benyahia B, Ribalta $\mathrm{T}$, et al. (2001) Anti-Hu-associated paraneoplastic encephalomyelitis: Analysis of 200 patients. Brain 124: 1138-1148.

7. Martinez ARM, Nunes MB, Nucci A, França MC (2012) Sensory neuronopathy and autoimmune disease.

8. Camdessanché JP, Antoine JC, Honnorat J, Vial C, Petiot P, et al. (2002) Paraneoplastic peripheral neuropathy associated with anti-Hu antibodies A clinical and electrophysiological study of 20 patients. Brain 125: 166-175.

9. Camdessanché JP, Jousserand G, Ferraud K, Vial C, Petiot $P$, et al. (2009) The pattern and diagnostic criteria of sensory neuronopathy: A case- control study. Brain 132: 1723-1733.

10. Kanaji N, Watanabe N, Kita N, Bandoh S, Tadokoro A, et al. (2014) Paraneoplastic syndromes associated with lung cancer. World Journal of Clinical Oncology 5: 197.

11. Senties-Madrid H, Vega-Boada F (2001) Paraneoplastic syndromes associated with anti-Hu antibodies. The Israel Medical Association Journal 3: 94-103.

12. Dalmau J, Graus F, Rosenblum MK, Posner JB (1992) Anti-Hu associated Paraneoplastic Encephalomyelitis/ SensoryNeuronopathy: A clinical Study of 71 patients. Medicine 71: 59-72.

13. Graus F, Dalmau J (2013) Paraneoplastic neuropathies. Current Opinion in Neurology 26: 489-495.

14. Dropcho EJ (1995) Autoimmune Central Nervous System Paraneoplastic Disorders: Mechanisms, Diagnosis, and Therapeutic Options. Ann Neurol 37: S102-S113.

15. Dalmau J, Rosenfeld MR (2008) Paraneoplastic Syndromes of the CNS. Lancet Neurology. NIH Public Access 7: $327-$ 340.

16. Rosales R, Go E, Canlas R (1997) Motor neuropathy as a remote effect of cancer. Philippine Journal of Internal Medicine. HERDIN database.

17. Croft PB, Henson RA, Urich H, Wilkinson PC (1964) Sensory Neuropathy with Bronchial Carcinoma: A Study of Four Cases Showing serological Abnormalities.

18. Sagar HJ, Read DJ (1982) Subacute sensory neuropathy with remission: An association with lymphoma. J Neurol Neurosurg Psychiatry 45: 83-85.

19. Plante-Bordeneuve V, Baudrimont M, Gorin NC, Gherardi RK (1994) Subacute sensory neuropathy associated with Hodgkin's disease. Journal of the Neurological Sciences 121: $155-158$. 
20. Oh BC, Lim YM, Kwon YM, Khang SK, Kim KK (2004) A Case of Hodgkin 's Lymphoma Associated with Sensory Neuropathy. Journal of Korean Medical Science 19: 130-133.
21. Tomita $M$, Koike $H$, Kawagashira $Y$, lijima $M$, Adachi $H$, et al. (2013) Clinicopathological features of neuropathy associated with lymphoma. Brain 136: 2563-2578. 